\title{
Effect of nitric oxide on mitochondrial activity of human synovial cells
}

Berta Cillero-Pastor ${ }^{1}$, Miguel A Martin², Joaquín Arenas ${ }^{2}$, María J López-Armada ${ }^{3 *}$, Francisco J Blanco ${ }^{1 *}$

\begin{abstract}
Background: Nitric oxide (NO) is a messenger implicated in the destruction and inflammation of joint tissues. Cartilage and synovial membrane from patients with rheumatoid arthritis (RA) and osteoarthritis (OA) have high levels of NO. NO is known to modulate various cellular pathways and, thus, inhibit the activity of the mitochondrial respiratory chain (MRC) of chondrocytes and induce the generation of reactive oxygen species (ROS) and cell death in multiple cell types. For these reasons, and because of the importance of the synovial membrane in development of OA pathology, we investigated the effects of $\mathrm{NO}$ on survival, mitochondrial function, and activity of fibroblastic human OA synovial cells.

Methods: Human OA synovia were obtained from eight patients undergoing hip joint replacement. Sodium nitroprusside (SNP) was used as a NO donor compound and cell viability was evaluated by MTT assays.

Mitochondrial function was evaluated by analyzing the mitochondrial membrane potential $(\Delta \psi m)$ with flow cytometry using the fluorofore DePsipher. ATP levels were measured by luminescence assays, and the activities of the respiratory chain complexes (complex I: $\mathrm{NADH} \mathrm{CoQ}_{1}$ reductase, complex II: succinate dehydrogenase, complex III: ubiquinol-cytochrome c reductase, complex IV: cytochrome c oxidase) and citrate synthase (CS) were measured by enzymatic assay. Protein expression analyses were performed by western blot.
\end{abstract}

Results: SNP at a concentration of $0.5 \mathrm{mM}$ induced cell death, shown by the MTT method at different time points. The percentages of viable cells at 24,48 and 72 hours were $86.11 \pm 4.9 \%, 74.31 \pm 3.35 \%$, and $43.88 \pm 1.43 \%$, respectively, compared to the basal level of $100 \%\left({ }^{*} p<0.05\right)$. SNP at $0.5 \mathrm{mM}$ induced depolarization of the mitochondrial membrane at 12 hours with a decrease in the ratio of polarized cells (basal $=2.48 \pm 0.28$; SNP 0.5 $\mathrm{mM}=1.57 \pm 0.11 ;{ }^{*} p<0.01$ ). The time course analyses of treatment with SNP at $0.5 \mathrm{mM}$ demonstrated that treatment reliably and significantly reduced intracellular ATP production $(68.34 \pm 14.3 \% \mathrm{vs}$. basal $=100 \%$ at 6 hours; $\left.{ }^{*} p<0.05\right)$. The analysis of the MRC at 48 hours showed that SNP at $0.5 \mathrm{mM}$ increased the activity of complexes I (basal = $36.47 \pm 3.92 \mathrm{~mol} / \mathrm{min} / \mathrm{mg}$ protein, SNP $0.5 \mathrm{mM}=58.08 \pm 6.46 \mathrm{~mol} / \mathrm{min} / \mathrm{mg}$ protein; ${ }^{*} p<0.05$ ) and III (basal = $63.87 \pm 6.93 \mathrm{~mol} / \mathrm{min} / \mathrm{mg}$ protein, SNP $0.5 \mathrm{mM}=109.15 \pm 30.37 \mathrm{~mol} / \mathrm{min} / \mathrm{mg}$ protein; ${ }^{*} p<0.05$ ) but reduced CS activity (basal $=105.06 \pm 10.72 \mathrm{~mol} / \mathrm{min} / \mathrm{mg}$ protein, SNP at $0.5 \mathrm{mM}=66.88 \pm 6.08 \mathrm{~mol} / \mathrm{min} / \mathrm{mg}$ protein.; $\left.{ }^{*} p<0.05\right)$, indicating a decrease in mitochondrial mass. Finally, SNP regulated the expression of proteins related to the cellular cycle; the NO donor decreased bcl-2, mcl-1 and procaspase-3 protein expression.

Conclusions: This study suggests that NO reduces the survival of OA synoviocytes by regulating mitochondrial functionality, as well as the proteins controlling the cell cycle.

\footnotetext{
* Correspondence: maria.jose.lopez.armada@sergas.es; fblagar@sergas.es

'Osteoarticular and Aging Research Unit, Biomedical Research Center, INIBIC,

CH Universitario da Coruña. Xubias 84, 15006, A Coruña, Spain

${ }^{3}$ Inflammation Unit, Biomedical Research Center, INIBIC, CH Universitario da

Coruña, Xubias 84, 15006, A Coruña, Spain

Full list of author information is available at the end of the article
} 


\section{Background}

Osteoarthritis (OA) is a common cartilage and joint disease related to age and characterized by a reduction in the number of chondrocytes, loss of the extracellular matrix, and synovial inflammation [1,2]. It has been shown that in the last phases of OA the synovial membrane plays an important role in the progression of the pathology. This tissue synthesizes inflammation mediators, such as cytokines [interleukin-1 $\alpha$ (IL-1 $\alpha)$, IL-1 $\beta$ and tumor necrosis factor- $\alpha$ (TNF- $\alpha)]$, proteases (collagenases and the aggrecanases), lipidic mediators [prostaglandin E2 (PGE2) and leukotriene B4 (LTB4)], and nitric oxide (NO) [3].

$\mathrm{NO}$ is a small hydrophobic molecule with chemical properties that make it uniquely suitable as both an intra- and intercellular messenger [4]. NO is produced in high quantities by the synovium and chondrocytes in rheumatoid pathologies, such as OA and rheumatoid arthritis (RA) [5-8]. Recent studies show that NO influences mitochondria, particularly in the activity of the mitochondrial respiratory chain (MRC). NO has many consequences on cell function, including cell death $[9,10]$. The mitochondrion is a complex organelle that, depending on the tissue type, has variable functions in cellular processes, such as controlling the oxidative state of the cell $[11,12]$. In addition, the mitochondrion plays an important role in energy production, predominantly in vascularised aerobic tissues, as a generator of ATP. The mitochondrion also regulates caspase-dependent and caspase-independent apoptotic pathways [13]. The classical signals for programmed cell death are preceded by mitochondrial alterations, which include loss of mitochondrial membrane potential $(\Delta \Psi)$, decrease in energy production, increase in the permeability of the mitochondrial membrane, alteration of MRC activities, release of pro-apoptotic factors, such as cytocrome c and downregulation of antiapoptotic members, such as bcl-2 and mcl-1, or activation of caspases pathways $[14,15]$.

A variety of NO donors suppress the mitochondrial respiration in different cell types, affecting energy production $[11,12]$. Our study demonstrates that sodium nitroprusside (SNP), a NO donor compound, reduces activity of complex IV of the MRC of chondrocytes, causing apoptotic cell death $[10,16]$. Because synovial cells are also affected in OA pathology, expressing high levels of iNOs and producing high quantities of NO [17-19], and because mitochondria may play a role in this highly vascular aerobic tissue, we examined the effects of SNP on synoviocyte survival relative to mitochondrial function.

\section{Methods}

\section{Procurement, processing and culture of synoviocytes}

Human OA synovia were obtained from patients undergoing hip joint replacement surgery at the Orthopaedic
Department of the Complejo Hospitalario Universitario da Coruña. Human OA synovial explants were enzymatically digested with $1.25 \mathrm{mg} / \mathrm{ml}$ bovine pancreas trypsin (Roche Diagnostics, Mannheim, Germany) for one hour with mixing at $37^{\circ} \mathrm{C}$. The cells were then centrifuged and resuspended in RPMI medium (BioWhittaker, Verviers, Belgium) enriched with $20 \%$ fetal calf serum (FCS) (Invitrogen, Carlsbad, CA, USA) and supplemented with $100 \mu \mathrm{l} / \mathrm{ml}$ glutamine (BioWhittaker), $100 \mu \mathrm{l} / \mathrm{ml}$ insulintransferrin-sodium selenite (Sigma-Aldrich, St Louis, $\mathrm{MO}$, USA). Culture was at $37^{\circ} \mathrm{C}$ in $5 \% \mathrm{CO}_{2}$ in a $162 \mathrm{~cm}^{2}$ flask (Costar, Cambridge, MA, USA) for four passages. After confluency was achieved, the cells were made quiescent by incubation for 24 hours in RPMI medium with $0.5 \%$ FCS before transfer to RPMI without FCS for the experiments. For the experiments, the cells were treated with the NO donor, SNP (Alexis Biochemicals, San Diego, CA, USA) at $0.5,1$ or $2 \mathrm{mM}$ for varying times of incubation, or with valinomycin at 1 $\mu \mathrm{M}$ for the depolarization experiments (Sigma-Aldrich). Controls were cultured under basal conditions, RPMI only. This study was approved by the Ethics Committee of Galicia-Spain.

\section{Cell viability MTT assay}

Cell viability $\left(12 \times 10^{3}\right.$ cells per well in a 96-well plate) was evaluated using a colorimetric MTT assay measuring reduction power (Roche Diagnostics). Following incubation of cells for different time points under basal conditions or with the experimental SNP concentrations, soluble tetrazolium salt solution $(10 \mu \mathrm{l}$ at $5 \mathrm{mg} / \mathrm{ml}$ in PBS) was added to the wells containing $100 \mu \mathrm{l}$ of medium and the plate was incubated for an additional 4 hours. $100 \mu \mathrm{l}$ of $10 \%$ SDS in $0.01 \mathrm{M} \mathrm{HCl}$ solubilization solution was then added to dissolve the water-insoluble formazan salt. Quantification with a spectrophotometer reader at $570 \mathrm{~nm}$ (GE Healthcare, Buckinghamshire, UK) was conducted.

\section{Determination of mitochondrial membrane potential $(\Delta \psi \mathrm{m})$}

To measure the $\Delta \psi m$ of synoviocytes, DePsipher (R\&D, Abingdon, UK), a lipophilic cation (5,5',6,6'-tetrachloro1,1'3,3'-tetraethylbenzimidazolyl carbocyanide iodide) was used. DePsipher exists as a monomer at low values of $\Delta \psi \mathrm{m}$ (green fluorescence) and forms aggregates at high $\Delta \psi \mathrm{m}$ (red fluorescence). Mitochondria with a normal $\Delta \psi \mathrm{m}$ concentrate DePsipher into aggregates (red fluorescence), but with a de-energized or depolarized $\Delta \psi \mathrm{m}$, DePsipher forms monomers (green fluorescence). For this procedure, synoviocytes were seeded at $25 \times$ $10^{4}$ cells per well in 6-well plates in serum-free medium (basal conditions) or treated with the different stimuli for 12 hours. Valinomycin at $1 \mu \mathrm{M}$ was utilized for the 
positive control. The synoviocytes collected by trypsinization were then incubated with $1 \mu \mathrm{l} / \mathrm{ml}$ DePsipher for 20 minutes at $37^{\circ} \mathrm{C}$ in $5 \% \mathrm{CO}_{2}$, sedimented, washed in PBS and analyzed by flow cytometry using FACScan (Becton Dickinson, Montain View, CA, USA) and CellQuest software (Becton Dickinson). The analyzer threshold was adjusted on the forward light scatter (FSC) channel to exclude most subcellular debris. Photomultiplier settings were adjusted to detect green fluorescence DePsipher monomer signals, centered at $\sim 390 \mathrm{~nm}$, on the FL1 detector, and red fluorescence DePsipher aggregate fluorescence signals, centered at $\sim 340 \mathrm{~nm}$, on the FL2 detector. Mean fluorescence intensity values for FL1 and FL2, expressed as arbitrary units, were obtained for all experiments. In each experiment, at least 20,000 events were analyzed. The percentage of depolarization in a cell population was calculated by dividing the values of red fluorescence by the values of green fluorescence.

\section{Measurement of synoviocyte ATP levels}

To determine intracellular ATP levels, a luminescent ATP detection assay system, based on the production of light from the reaction of ATP with luciferase and D-luciferin, was employed (Perkin Elmer, Barcelona, Spain). Synoviocytes were seeded at $5 \times 10^{4}$ cells per well in 96-well plates. Following incubation with or without SNP at $0.5 \mathrm{mM}, 50 \mu \mathrm{l}$ per well of mammalian cell lysis solution was added and the plate was shaken for five minutes in an orbital shaker. $50 \mu \mathrm{l}$ of a substrate solution was then added and the microplate was shaken for another five minutes. The plate was dark-adapted for 10 minutes, and the emitted light was measured by luminometry in a Micro Beta TriLux (Perkin Elmer).

\section{Measurement of MRC complex activities in digitonin- permeabilized synoviocytes}

Synoviocytes $\left(3.5 \times 10^{6}\right.$ per $140 \mathrm{~mm}$ diameter Petri dish) were stimulated with SNP at $0.5 \mathrm{mM}$ for 48 hours. Synoviocytes grown in basal medium served as controls. The cells were collected by trypsinization, washed with phosphate buffered saline (PBS) and centrifuged at 150xg for five minutes at $4^{\circ} \mathrm{C}$. The pellet was resuspended in $2 \mathrm{ml}$ of ice-cold solution containing $20 \mathrm{mM}$ MOPS, $0.25 \mathrm{M}$ sucrose and $200 \mu \mathrm{g}$ of digitonin per $5 \times 10^{6}$ cells. After five minutes incubation on ice, the suspension was centrifuged at $5,000 \times g$ for three minutes at $4^{\circ} \mathrm{C}$. The resulting pellet was resuspended in $1.5 \mathrm{ml}$ of $20 \mathrm{mM}$ MOPS, $0.25 \mathrm{M}$ sucrose and $1 \mathrm{mM}$ of EDTA buffer, incubated for five minutes and centrifuged at $10,000 \times g$ for three minutes at $4^{\circ} \mathrm{C}$. Finally, the pellet was resuspended in $200 \mu \mathrm{l}$ $10 \mathrm{mM}$ phosphate buffer (KP, pH 7.4), frozen and thawed once, then mildly sonicated. These digitonin-permeabilized homogenates were used to measure the activities of respiratory chain enzymes and CS using a DU-650 spectrophotometer (Beckman Instruments, Palo Alto, $\mathrm{CA}$ ). Incubation temperatures were $30^{\circ} \mathrm{C}$ for rotenonesensitive NADH-coenzyme $\mathrm{Q}_{1}$ reductase (complex I), succinate dehydrogenase (SDH; complex II), antimycinsensitive ubiquinol cytochrome $c$ reductase (complex III) and CS, and $38^{\circ} \mathrm{C}$ for cytochrome $c$ oxidase (complex IV). To correct for mitochondrial volume, enzyme activities were normalized to the specific activity of CS. Complex I was measured by the oxidation of NADH at $340 \mathrm{~nm}$ in $20 \mathrm{mM}$ KP (pH 8.0), $200 \mu \mathrm{M}$ NADH, $1 \mathrm{mM} \mathrm{NaN}_{3}, 0.1 \%$ bovine serum albumin (BSA)-EDTA, and $100 \mu \mathrm{M}$ ubiquinone-1 (Sigma), first without rotenone (Calbiochem, La Jolla, CA, USA), then with $5 \mu \mathrm{M}$ rotenone added so a rotenone-sensitive rate of NADH oxidation could be calculated. Complex II (SDH) activity was assessed by the reduction of 2,6-dichlorophenolindophenol (DCPIP) (Sigma) at $600 \mathrm{~nm}$ in $50 \mathrm{mM}$ Tris-KP (pH 7.0), $1.5 \mathrm{mM}$ KCN, $100 \mu \mathrm{M}$ DCPIP, and $32 \mathrm{mM}$ succinate (Sigma). Complex III was assayed by measuring the reduction of cytochrome $c$ at $550 \mathrm{~nm}$ in $50 \mathrm{mM} \mathrm{KP}$ (pH 7.5), $2 \mathrm{mM}$ $\mathrm{NaN}_{3}, 0.1 \%$ BSA-EDTA, $50 \mu \mathrm{M}$ cytochrome $c$ (Roche) and $50 \mu \mathrm{M}$ decyl-ubiquinol (Sigma), first without antimicyn A (Sigma) and then with $0.01 \mathrm{mg} / \mathrm{ml}$ of antimycin A added, so an antimicyn A-sensitive rate of cytochrome $c$ reduction could be calculated. Complex IV was measured by the oxidation of reduced cytochrome $c$ at $550 \mathrm{~nm}$ in $10 \mathrm{mM} \mathrm{KP}$ (pH 7.0) and $80 \mu \mathrm{M}$ reduced cytochrome, which was freshly prepared before each experiment by adding sodium dithionite (Sigma). CS was evaluated at $420 \mathrm{~nm}$ in $75 \mathrm{mM}$ Tris- $\mathrm{HCl}(\mathrm{pH} 8), 100 \mu \mathrm{M}$ 5,5'-dithiobis-(2-nitrobenzoic) acid (Sigma), $350 \mu \mathrm{g} / \mathrm{ml}$ acetylcoenzyme A (Sigma), $0.5 \mathrm{mM}$ oxaloacetate (Roche Diagnostics) and 0.1\% Triton X-100 (Sigma).

\section{Western blot}

Cells $\left(1.5 \times 10^{6}\right.$ per $100 \mathrm{~mm}$ diameter Petri dish) were incubated with SNP at $2 \mathrm{mM}$ for 48 hours or in basal conditions. After incubation, the cells were washed in ice-cold PBS pH 7.5 and lysed in $0.2 \mathrm{M}$ Tris- $\mathrm{HCl} \mathrm{pH}$ 6.8 containing $2 \%$ SDS, $20 \%$ glycerol, $1 \mu \mathrm{g} / \mathrm{ml}$ cocktail inhibitor and $1 \mathrm{mM}$ phenyl methyl sulfonyl fluoride (PMSF) (Sigma). Samples were boiled for 5 minutes and protein concentrations were determined using the BCA reagent assay (Pierce Chemical Co., Rockford, IL, USA). Thirty $\mu \mathrm{g}$ of the protein extract were resolved on $12.5 \%$ SDS-polyacrylamide gels, then transferred to polyvinylidene difluoride membranes (Immobilon P, Millipore Co., Bedford, MA, USA). These membranes were first blocked in Tris buffered saline (TBS) $\mathrm{pH} 7.4$, containing $0.1 \%$ Tween-20 (Invitrogen) and 5\% nonfat dried milk for 60 minutes at room temperature, then incubated overnight with mouse anti-human bcl-2 1:2000 (R\&D), mouse anti-human mcl-1 1:500 (Oncogene, Cambridge MA, US) or mouse anti-human caspase 3 1:2000 (R\&D) 
in fresh blocking solution at $4^{\circ} \mathrm{C}$. After washing, the membranes were incubated with peroxidase conjugated secondary antibodies, developed using the ECL chemiluminescence kit (GE Healthcare) and digitized using LAS 3000 image analyzer. Quantitative changes in band intensities were evaluated using ImageQuant 5.2 software (GE Healthcare). Densitometric values for the Western blot bands containing the protein of interest were normalized against those of $\alpha$-tubulin (Sigma) obtained from the same sample.

\section{Statistical analyses}

The data are expressed as the mean \pm SE from the determinations as described. Individual donors were studied in duplicate; pooled cells from different donors were not used in any experiment. The statistical software program, SPSS (version 15.0, SPSS, Chicago, IL, USA) was used to perform the analysis of variance (ANOVA) and Tukey tests. Differences were considered to be statistically significant at $p \leq 0.05$.

\section{Results}

\section{Effect of NO on synoviocyte viability}

Analyses of viability using MTT assay methods to measure the cellular reduction power showed that the NO donor, SNP, reduced synoviocyte viability with a time-dependent decrease in the percentages (figure 1). At 24, 48 and 72 hours of incubation, respectively: SNP at $0.5 \mathrm{mM}: 86.11 \pm$ $4.9 \%, 74.31 \pm 3.35 \%, 43.88 \pm 1.43 \%$ vs. $100 \%$ basal; SNP at $1 \mathrm{mM}$ : $85.52 \pm 5.91 \%, 11.91 \pm 0.72 \%, 7.1 \pm 0.41 \%$ vs. $100 \%$ basal; and SNP at $2 \mathrm{mM}$ : $77.85 \pm 6.46 \%, 15 \pm 0.52 \%, 10.85$ $\pm 0.56 \%$ vs. basal $100 \%$, $([\mathrm{n}=8] ; * p<0.05)$.

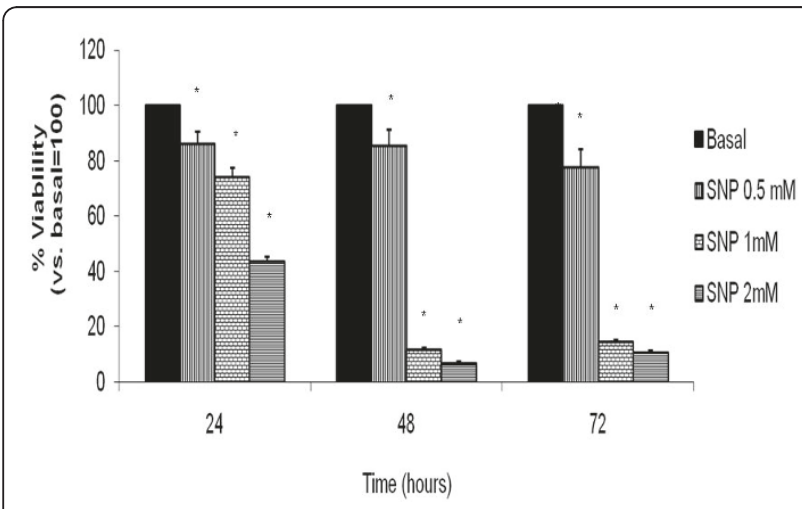

Figure 1 Effect of sodium nitroprusside (SNP) on the cell viability of human osteoarthritic (OA) synoviocytes. Human OA synoviocytes were incubated under basal conditions (RPMI only) or with SNP at concentrations of 0.5, 1 and $2 \mathrm{mM}$ for 24, 48 and 72 hours. Cell viability was evaluated using a colorimetric analysis based on the MTT assay as detailed in the Methods section. The data are expressed as percentages of those of the control conditions (100\%), and represent the mean \pm standard error of eight different experiments performed in duplicate $\left({ }^{*} p<0.05\right)$.

\section{Effect of SNP on mitochondria}

A second set of experiments examined the effects of SNP on mitochondrial function by determining the $\Delta \psi \mathrm{m}, \mathrm{ATP}$ synthesis and activities of the respiratory chain complexes I-IV and CS. To assess the effect of SNP on the $\Delta \psi \mathrm{m}$ of synoviocytes, the fluoresecent probe DePsipher was used. The staining pattern of DePsipher for basal synoviocytes was established as the standard. The total cell population was divided into two subsets: one with normal $\Delta \psi \mathrm{m}$ (red fluorescence or high levels of FL-2), as the left upper panels represent in figure $2 \mathrm{~A}$, and another with lower $\Delta \psi \mathrm{m}$ (green fluorescence or high levels of FL-1), as the right lower panels represent in figure $2 \mathrm{~A}$. The treatment of synoviocytes with SNP at $0.5 \mathrm{mM}$ for 12 hours reduced the percentage of cells with normal mitochondrial polarization [basal: $48.08 \pm 3.59 \%$; SNP at $0.5 \mathrm{mM}$ : $36.04 \pm$ $2.77 \%$; and valinomycin at $1 \mu \mathrm{M}: 17.04 \pm 2.38 \%(\mathrm{n}=8$, ${ }^{*} p<0.01$ )] (Figure 2A) and increased the number of cells with mitochondrial depolarization [basal: $6.76 \pm 2.14 \%$; SNP at $0.5 \mathrm{mM}$ : $9.96 \pm 1.45 \%$; and valinomycin at $1 \mu \mathrm{M}$ : $26.87 \pm 2.92 \%,\left(\mathrm{n}=8,{ }^{*} p<0.01\right)$ ] (Figure $\left.2 \mathrm{~A}\right)$. SNP treatment at $0.5 \mathrm{mM}$ caused a significant decrease in the red/ green fluorescence ratio (basal: $2.48 \pm 0.28$; SNP at $0.5 \mathrm{mM}: 1.57 \pm 0.11$; and valinomycin at $1 \mu \mathrm{M}: 0.93 \pm$ 0.06, $(\mathrm{n}=8, * p<0.01)$ ] (figure $2 \mathrm{~B})$.

We also assessed the effects of SNP on ATP production. Treatment with SNP at $0.5 \mathrm{mM}$ for 6, 24, 48 and 72 hours significantly decreased ATP production [6 hours: $68.34 \pm 14.3 \%$; 24 hours: $75.04 \pm 13.32 \%$; 48 hours: 75.28 $\pm 12.94 \%$; and 72 hours: $75.54 \pm 16.3 \%$, compared to the basal value of $100 \%,(\mathrm{n}=8) * p<0.05)$ ] (figure 3$)$. These results indicate that SNP affects mitochondrial function, therefore, we evaluated the MRC activity of human OA synoviocytes treated with SNP at $0.5 \mathrm{mM}$ for 48 hours. Figure 4 shows that the NO donor induced an increase in activity of complex I (basal: $36.47 \pm 3.92 \mathrm{~mol} / \mathrm{min} / \mathrm{mg}$ prot.; SNP at $0.5 \mathrm{mM}$ : $58.08 \pm 6.46 \mathrm{~mol} / \mathrm{min} / \mathrm{mg}$ prot.) and of complex III (basal: $63.87 \pm 6.93 \mathrm{~mol} / \mathrm{min} / \mathrm{mg}$ prot.; SNP at $0.5 \mathrm{mM}$ : $109.15 \pm 30.37 \mathrm{~mol} / \mathrm{min} / \mathrm{mg}$ prot.), $\left(\mathrm{n}=6,{ }^{*} p<0.05\right)$. However, SNP at $0.5 \mathrm{mM}$ produced a decrease in the activity of CS [basal: $105.06 \pm 10.72 \mathrm{~mol} /$ $\mathrm{min} / \mathrm{mg}$ prot.; SNP at $0.5 \mathrm{mM}: 66.88 \pm 6.08 \mathrm{~mol} / \mathrm{min} / \mathrm{mg}$ prot., $\left.\left(\mathrm{n}=6,{ }^{*} p<0.05\right)\right]$, which indicates a reduction in mitochondrial mass.

\section{Effect of SNP on cell cycle protein expression}

Mitochondria are one of the initiators of apoptosis and regulate the cell cycle because they modulate the activity of anti- or pro-apoptotic elements, such as bcl-2 and the caspase family. To define the proteins implicated in SNP mitochondrial regulation and in induced death, we studied the expression pattern of bcl- 2 and mcl- 1 antiapoptotic proteins, as well as the pro-apoptotic caspase 3 . We observed that levels of bcl- 2 protein in OA 


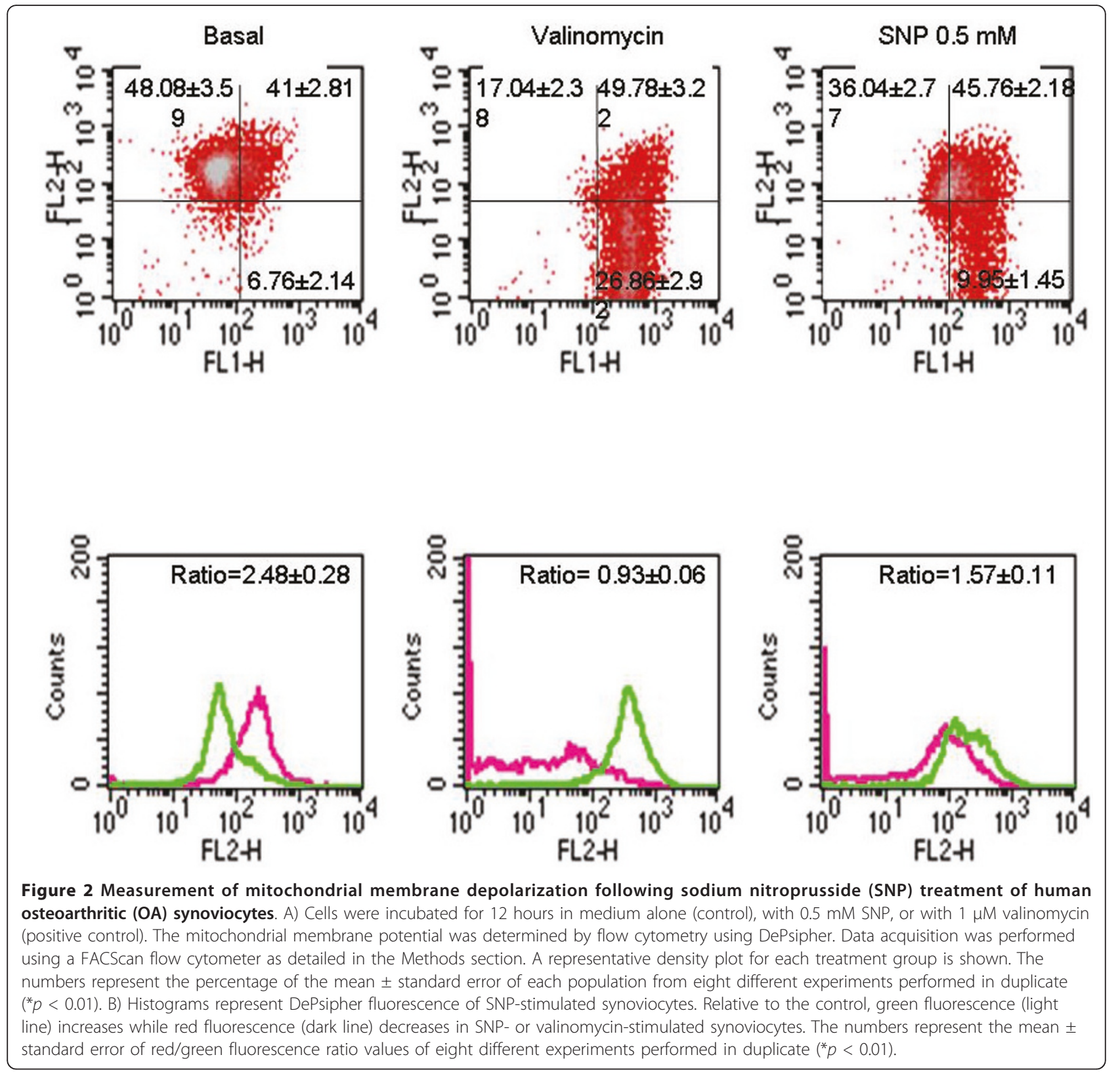

synoviocytes were downregulated by treatment with 2 mM SNP at $48 \mathrm{~h}[(47.75 \pm 18.93 \%$ vs. basal $100 \%$, $(\mathrm{n}=$ 4 ; " $p<0.05$ )] (figure 5A), as well those of mcl-1 [48.67 $\pm 15.00 \%$ vs. basal 100\%, $\left(\mathrm{n}=3\right.$; ${ }^{*} p<0.05$ ] (figure $\left.5 \mathrm{~B}\right)$. We also found a decrease in the inactive proform of caspase 3 detected after treatment with SNP at $2 \mathrm{mM}$ for 48 hours $[66.02 \pm 8.64$ vs. basal $100 \%,(\mathrm{n}=3)$; " $p<$ 0.05) (figure 5C)]. A representative experiment of each analysis is shown in figure $5 \mathrm{D}$.

\section{Discussion}

In OA pathology, the process leading to an aberrant cartilage structure characterized by reduction in the number of chondrocytes, loss of extracellular matrix, synovial inflammation, and irregular proliferation and death of synoviocytes is time- or age-dependent [20-22]. The pathogenesis of OA includes increased NO levels by chondrocytes and synovial cells as a consequence of the up-regulation of NO synthase (NOS) induced by IL$1 \beta$, TNF- $\alpha$ and other factors [23]. The role of NOS has been of interest in the pathogenesis of OA because of its role in the induction of chondrocyte and synoviocyte death [10]. Our earlier study established that the NO donor, SNP, induced an increase in hypodiploid DNA of human chondrocytes. It also induced mRNA expression of caspase- 7 and reduced the expression of mRNA and protein synthesis of bcl-2 by human chondrocytes [10]. Further, SNP reduced chondrocyte survival and induced 


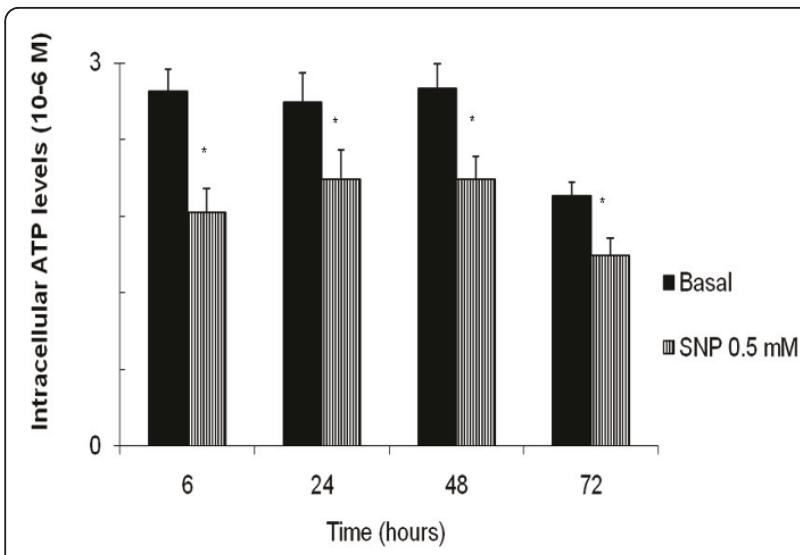

Figure 3 ATP production of synoviocytes stimulated with sodium nitroprusside (SNP). Synoviocytes were cultured in basal conditions (only RPMI) or treated with SNP at $0.5 \mathrm{mM}$ for $6,24,48$ and 72 hours and collected for whole cell ATP measurement as described in the Methods section. ATP values are expressed as the mean \pm standard error of eight different experiments performed in duplicate $\left({ }^{*} p<0.05\right)$.

cell death with morphologic changes characteristic of chondrocyte apoptosis.

Mitochondria are important organelles in most cells and, particularly, in aerobic tissues, such as the synovial membrane. Pertaining to the importance of mitochondria in OA pathology, Rego et al. found that some haplogroups of mitochondrial respiratory genes of chondrocytes confer increased predisposition to the development of OA [24]. Also, the activity of the mitochondrial complexes II and III is lower in OA than in normal human chondrocytes. This produces a decrease in ATP levels as well as a higher reactive oxygen species (ROS) generation $[25,26]$. Mitochondrial complex inhibitors, such as antimycin A and oligomycin, induce ROS production, NF- $\kappa$ B activation, COX expression and PGE2 production in chondrocytes in culture [27]. In rabbit and human chondrocytes, SNP suppresses mitochondrial respiration by reducing oxygen consumption and by diminishing ATP levels $[25,28]$. In human chondrocytes, SNP decreased the $\Delta \psi \mathrm{m}$ as measured by the ratio of red/ green fluorescence of DePsipher and inhibited the activity of complex IV of the MRC [10]. Regulation of the MRC may be a signalling pathway by which NO modulates articular cartilage matrix biosynthesis and pathologic mineralization. There are no previous studies of mitochondrial integrity in relation to the energy production in synoviocytes, although some mtDNA somatic mutations and the importance of normal $\Delta \psi \mathrm{m}$ have been studied $[29,19]$. Because the synovial membrane is an aerobic tissue, we speculated that mitochondrial integrity is necessary for synoviocyte survival. Studies have shown that proteins that are clearly regulated by mitochondria, such

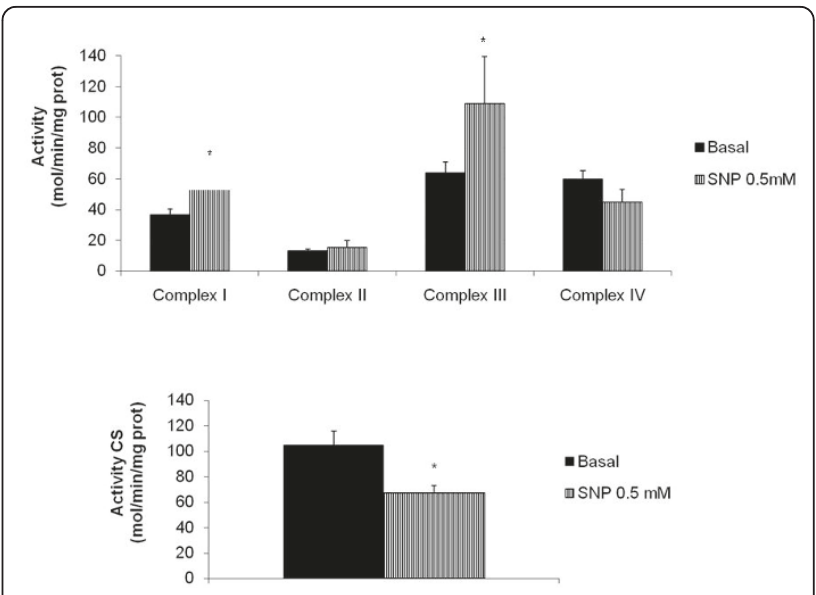

Figure 4 Activity of mitochondrial respiratory chain (MRC) complexes of osteoarthritic (OA) synoviocytes incubated with sodium nitroprusside (SNP). A) Confluent synoviocytes were incubated for 48 hours under basal conditions (RPMI only) or with SNP at $0.5 \mathrm{mM}$ and MRC complex activities were measured as reported in Methods. Citrate synthase (CS)-corrected complex activity is expressed as $\mathrm{nmol} / \mathrm{min} / \mathrm{mg}$ protein/CS specific activity x100. Complex I = rotenone-sensitive NADH-coenzyme Q1 reductase; Complex II = succinate dehydrogenase; Complex III = antimycin-sensitive ubiuqinol cytocrome $\mathrm{c}$ reductase; Complex IV = cytocrome $c$ oxidase. The values are the mean \pm standard error of six experiments performed in duplicate $\left({ }^{*} p<0.05\right)$. B) The activity of CS following stimulation with SNP at $0.5 \mathrm{mM}$ was evaluated. The values are the mean \pm standard error of six experiments performed in duplicate $\left({ }^{*} p<0.05\right)$.

as the bcl-2 family, regulate the viability of synoviocytes [30]. Previous studies also found that NO induced synoviocyte death by regulating the expression of the protein p53 and the activation of caspase 3, although we found no publications concerning the importance of the MRC in synoviocyte ATP production $[31,32,19]$. For these reasons, we set out to study the effects of NO in relation to mitochondrial function in human OA synoviocytes. In our study, the NO donor SNP was able to reduce the survival of synoviocytes, as expected. We observed that SNP increased the hypodiploid cell number (data not shown), similar to an apoptotic or similar programmed cell death, as other authors have elucidated [19,31]. We thought that this decrease in cell viability might be due in part to the effect of $\mathrm{NO}$ on mitochondrial function. From our results, we have concluded that SNP depolarized $\Delta \psi \mathrm{m}$ and, as a probable consequence of irregular electron distribution along this membrane, we found a reduction in ATP production. However, the activities of the MRC complexes I and III were increased, possibly due to an adaptive effort by damaged synovial cells to produce more energy. We also found a decrease in CS activity, indicating a reduction in the mitochondria mass following SNP treatment, probably causing the ATP depletion. Apart from mitochondrial dysfunction, another explanation for the lowered ATP 


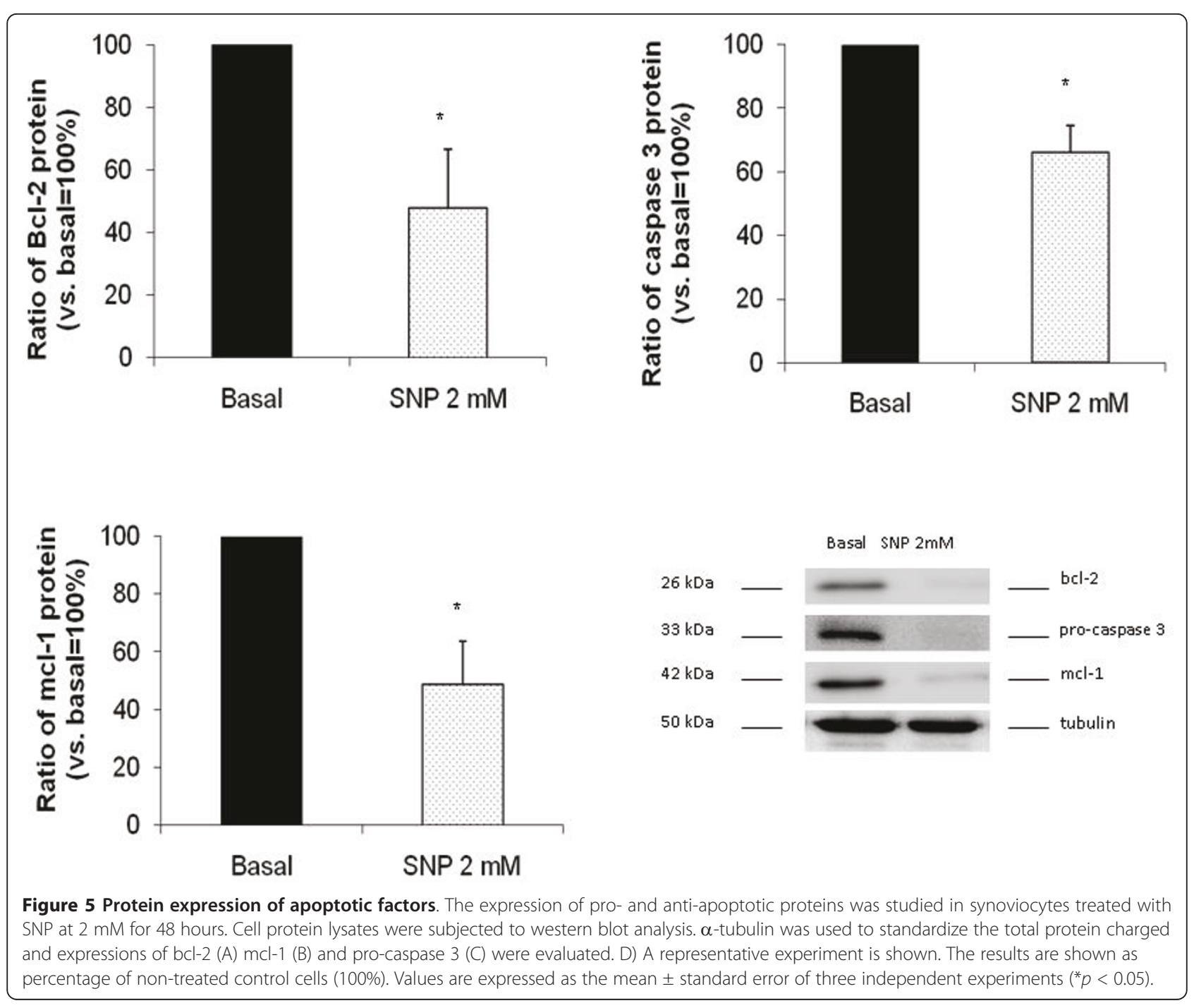

levels could be that SNP reduces the expression of G3PDH protein, an important enzyme in glucose metabolism in OA synoviocytes [33]. It appears that SNP binds to glucose receptors irreversibly [33], impacting the glycolytic pathway and generation of energy. The low levels of ATP explain why the synoviocytes die. We also were able to show that the mcl-1 and bcl-2 anti-apoptotic proteins were downregulated in the presence of SNP after 48 hours of treatment, helping to explain the programmed cell death NO induces [34]. Another study has shown that mcl-1 has an important role in neuron survival before and after damage to DNA [35]. The full length of caspase 3 was also decreased, probably because it was transformed to the smaller activated state, as other investigators have shown [19]. Direct investigation of the functions of NO production by chondrocytes has been hampered by the lack of uniformity existing among different types of NO donor compounds employed in the experiments [36]. The majority of studies have used SNP for the NO donor compound, and results show that it reduces cell survival and induces cell death with the morphologic changes characteristic of apoptosis [10,19]. A second possible explanation for the finding that $\mathrm{NO}$ reduced cell survival in all these cell types may lie in the interaction of additional reactive oxygen species (ROS), possibly concomitantly produced as a consequence of NO itself [19]. Also, an increase in intracellular levels of ROS from increased activity of MRC complexes I and III provides a condition where the intracellular redox status of the cell could be altered $[37,38]$. In this case, the action of NO on $\Delta \psi \mathrm{m}$ would increase the production of ROS by mitochondria and also the cytotoxicity associated with $\mathrm{NO}$ and some reactive nitrogen species (RNS), such as peroxynitrite [19]. A recent study on peroxynitrite mediated-chondrocyte apoptosis found that the predominant mode of cell death involved calcium-dependent cysteine proteases, known as calpains, and that peroxynitrite induced mitochondrial dysfunction in cells leading to caspase-independent 
apoptosis [39]. This hypothetical elevation of ROS and RNS production can form nitrotyrosine complexes with other proteins, increasing and amplifiying the effects that $\mathrm{NO}$ alone has as shown in joint tissues from OA and RA patients [40-42].

\section{Conclusions}

In this study we demonstrated and elucidated the important role that NO has in mitochondrial integrity, in energy production and in regulation of the survival of synoviocytes. This information helps us understand the role of mitochondria in the development of OA pathology.

\section{Abbreviations}

ATP: adenosine triphosphate; CS: citrate synthase; IL: interleukin; iNOS: inducible nitric oxide synthase; LTB4: leucotrien B4; MRC: mitochondrial respiratory chain; $\mathrm{mg}$ : milligram; min: minute; $\mathrm{mm}$ : millimetre; $\mathrm{mM}$ : millimolar; NO: nitric oxide; RA: rheumatoid arthtritis; OA: osteoarthtritis; Prot: proteins; ROS: reactive oxygen species; PGE2: prostaglandin 2; SNP: sodium nitroprusside; TNF-a: tumor necrosis factor alpha; $\mu$ g: micro gram; $\mu$ : micro liter; $\mu \mathrm{M}$ : micro molar.

\section{Acknowledgements}

This study was supported by grants from Ministerio Ciencia en Innovación PLE2009-0144; Instituto de Salud Carlos III CIBER BBN CB06-01-0040 and FISPI 08/2028 with participation of fundus from FEDER (European Community). MJ López-Armada was supported by grants from Fondo Investigación Sanitaria. B Cillero-Pastor is the recipient of an Angeles Alvariño grant from Xunta de Galicia.

\section{Author details}

'Osteoarticular and Aging Research Unit, Biomedical Research Center, INIBIC, CH Universitario da Coruña. Xubias 84, 15006, A Coruña, Spain. ${ }^{2}$ Laboratorio de Investigación, Hospital 12 de Octubre, Madrid, Spain. Inflammation Unit, Biomedical Research Center, INIBIC, CH Universitario da Coruña, Xubias 84, 15006, A Coruña, Spain.

\section{Authors' contributions}

BCP carried out the synoviocyte cultures, molecular genetic studies, western blot experiments, performed the statistical analysis and drafted the manuscript. MAM and JA measured the MRC complex activities in digitoninpermeabilized synoviocytes, determined the mitochondrial membrane potential, and measured synoviocyte ATP levels. MJLA participated in the design and coordination of the study. FJB conceived the idea of the study, and participated in its design and coordination. All authors read and approved the final manuscript.

\section{Competing interests}

\section{Financial competing interests}

In the past five years, we have not received any reimbursements, fees, funding, or salary from any organization that may in any way gain or lose financially from the publication of this manuscript.

There is no organization financing this manuscript (including the article processing charge).

We do not hold any stocks or shares in any organization that may in any way gain or lose financially from the publication of this manuscript. We do not currently hold any patents nor are we applying for any patents relating to the content of the manuscript.

We have not received reimbursements, fees, funding, or salary from any organization that holds or has applied for patents relating to the content of the manuscript.

\section{Non-financial competing interests}

There are no non-financial competing interests (political, personal, religious, ideological, academic, intellectual, commercial or any other) to declare in relation to this manuscript.
Received: 6 October 2010 Accepted: 8 February 2011

Published: 8 February 2011

\section{References}

1. Bullough P: The pathology of osteoarthritis. In Osteoarthritis: diagnosis and medical/surgical management. Edited by: Moskowitz RW, Howell DS, Goldberg VM, Mankin HJ. Philadelphia: WB Saunders; 1984:39-69.

2. Roach HI, Aigner T, Soder S, Haag J, Welkerling H: Pathobiology of osteoarthritis: pathomechanisms and potential therapeutic targets. Curr Drug Targets 2007, 8:271-82.

3. Sutton S, Clutterbuck A, Harris P, Gent T, Freeman S, Foster N, BarrettJolley R, Mobasheri A: The contribution of the synovium, synovial derived inflammatory cytokines and neuropeptides to the pathogenesis of osteoarthritis. Vet J 2009, 179:10-24.

4. Moncada S, Higgs A: The L-Arginine-Nitric Oxide Pathway. N Engl J 1993, 329:2002-12.

5. Hilliquin P, Borderie D, Hernvann A, Menkes CJ, Ekindjian OG: Nitric oxide as S-nitrosoproteins in rheumatoid arthritis. Arthritis Rheum 1997, 40:1512-77.

6. Evans $\mathrm{CH}$, Stefanovic-Racic M, Lancaster J: Nitric oxide and its role in orthopaedic disease. Clin Orthop 1995, 312:275-94.

7. Vuolteenaho K, Moilanen T, Knowles RG, Moilanen E: The role of nitric oxide in osteoarthritis. Scand J Rheumatol 2007, 36:247-58.

8. Rediske J, Koehne CF, Zhang B, Lotz M: The inducible production of nitric oxide by articular cell types. Osteoarthritis Cartilage 1994, 2:199-206.

9. Green DR, Kroemer G: The pathophysiology of mitochondrial cell death. Science 2004, 305:626-9.

10. Maneiro E, López-Armada MJ, de Andres MC, Caramés B, Martín MA, Bonilla A, Del Hoyo P, Galdo F, Arenas J, Blanco FJ: Effect of nitric oxide on mitochondrial respiratory activity of human articular chondrocytes. Ann Rheum Dis 2005, 64:388-95.

11. Roy A, Ganguly A, BoseDasgupta S, Das BB, Pal C, Jaisankar P, Majumder HK: Mitochondria-dependent reactive oxygen species-mediated programmed cell death induced by 3,3'-diindolylmethane through inhibition of FOF1-ATP synthase in unicellular protozoan parasite Leishmania donovani. Mol Pharmacol 2008, 74:1292-307.

12. Reddy PH: Role of mitochondria in neurodegenerative diseases: mitochondria as a therapeutic target in Alzheimer's disease. CNS Spectr 2009, 14:8-13.

13. Kim R, Emi M, Tanabe K: Caspase-dependent and -independent cell death pathways after DNA damage. Oncol Rep 2005, 14:595-9.

14. Knudson CM, Brown NM: Mitochondria potential, bax "activation," and programmed cell death. Methods Mol Biol 2008, 414:95-108.

15. Gupta S, Kass GE, Szegezdi E, Joseph B: The mitochondrial death pathway: A promising therapeutic target in Diseases. I Cell Mol Med 2009, 13:1004-33.

16. Wu GJ, Chen TG, Chang HC, Chiu WT, Chang CC, Chen RM: Nitric oxide from both exogenous and endogenous sources activates mitochondriadependent events and induces insults to human chondrocytes. J Cell Biochem 2007, 101:1520-31.

17. Sakurai H, Kohsaka H, Liu MF, Higashiyama H, Hirata Y, Kanno K, Saito I, Miyasaka N: Nitric oxide production and inducible nitric oxide synthase expression in inflammatory arthritides. J Clin Invest 1995, 96:2357-63.

18. Mclnnes IB, Leung BP, Field M, Wei XQ, Huang FP, Sturrock RD, Kinninmonth A, Weidner J, Mumford R, Liew FY: Production of nitric oxide in the synovial membrane of rheumatoid and osteoarthritis patients. $J$ Exp Med 1996, 184:1519-24.

19. Jovanovic DV, Mineau F, Notoya K, Reboul P, Martel-Pelletier J, Pelletier JP: Nitric oxide induced cell death in human osteoarthritic synoviocytes is mediated by tyrosine kinase activation and hydrogen peroxide and/or superoxide formation. I Rheumatol 2002, 29:2165-75.

20. Kühn K, D'Lima DD, Hashimoto S, Lotz M: Cell death in cartilage. Osteoarthritis Cartilage 2004, 12:1-16.

21. López-Armada MJ, Caramés B, Cillero-Pastor B, Blanco FJ: Fisiopatología de la artrosis. Rev Esp Reum 2004, 31:399-93.

22. Goldring MB, Goldring SR: Osteoarthritis. J Cell Physiol 2007, 213:626-34.

23. Abramson SB: Inflammation in osteoarthritis. J Rheumatol 2004, 70:70-6.

24. Rego I, Fernández-Moreno M, Fernández-López C, Gómez-Reino JJ, González A, Arenas J, Blanco FJ: Role of European mitochondrial DNA haplogroups in the prevalence of hip osteoarthritis in Galicia, Northern Spain. Ann Rheum Dis 2010, 69:210-3. 
25. Johnson K, Jung A, Murphy A, Andreyev A, Dykens J, Terkeltaub R: Mitochondrial oxidative phosphorylation is a downstream regulator of nitric oxide effects on chondrocyte matrix synthesis and mineralization. Arthritis Rheum 2000, 43:1560-70.

26. Maneiro E, Martín MA, de Andres MC, López-Armada MJ, FernándezSueiro JL, del Hoyo P, Galdo F, Arenas J, Blanco FJ: Mitochondrial respiratory activity is altered in osteoarthritic human articular chondrocytes. Arthritis Rheum 2003, 48:700-8.

27. Cillero-Pastor B, Caramés B, Lires-Deán M, Vaamonde-García C, Blanco FJ, López-Armada MJ: Mitochondrial dysfunction activates cyclooxygenase 2 expression in cultured normal human chondrocytes. Arthritis Rheum 2008, 58:2409-19.

28. Tomita M, Sato EF, Nishikawa M, Yamano Y, Inoue M: Nitric oxide regulates mitochondrial respiration and functions of articular chondrocytes. Arthritis Rheum 2001, 44:96-104

29. Da Sylva TR, Connor A, Mburu Y, Keystone E, Wu GE: Somatic mutations in the mitochondria of rheumatoid arthritis synoviocytes. Arthritis Res Ther 2005, 7:844-51.

30. Perlman H, Georganas C, Pagliari $L$, Koch AE, Haines K, Pope RM: Bcl-2 expression in synovial fibroblasts is essential for maintaining mitochondrial homeostasis and cell viability. J Immunol 2000, 164:5227-35.

31. Borderie D, Hilliquin P, Hernvann A, Lemarechal $H$, Menkes CJ, Ekindjian OG: Apoptosis induced by nitric oxide is associated with nuclear p53 protein expression in cultured osteoarthritic synoviocytes. Osteoarthritis Cartilage 1999, 7:203-13.

32. Aupperle KR, Boyle DL, Hendrix M, Seftor EA, Zvaifler NJ, Barbosa M, Firestein GS: Regulation of synoviocyte proliferation, apoptosis, and invasion by the p53 tumor suppressor gene. Am J Pathol 1998, 152:1091-8.

33. Borderie D, Le Marechal H, Ekindjian OG, Hernvann A: Nitric oxide modifies glycolytic pathways in cultured human synoviocytes. Cell Biol Int. 2000, 24:285-9.

34. Cherng YG, Chang HC, Lin YL, Kuo ML, Chiu WT, Chen RM: Apoptotic insults to human chondrocytes induced by sodium nitroprusside are involved in sequential events, including cytoskeletal remodeling, phosphorylation of mitogen-activated protein kinase kinase kinase-1/cJun N-terminal kinase, and Bax-mitochondria-mediated caspase activation. J Orthop Res 2008, 26:1018-26.

35. Arbour N, Vanderluit JL, Le Grand JN, Jahani-Asl A, Ruzhynsky VA, Cheung EC, Kelly MA, MacKenzie AE, Park DS, Opferman JT, Slack RS: Mcl-1 is a key regulator of apoptosis during CNS development and after DNA damage. J Neurosci 2008, 28:6068-78.

36. Del Carlo M Jr, Loeser RF: Nitric oxide-mediated chondrocyte cell death requires the generation of additional reactive oxygen species. Arthritis Rheum 2002, 46:394-403.

37. Tephly LA, Carter AB: Constitutive NADPH oxidase and increased mitochondrial respiratory chain activity regulate chemokine gene expression. Am J Physiol Lung Cell Mol Physiol 2007, 293:1143-55.

38. Grobe AC, Wells SM, Benavidez E, Oishi P, Azakie A, Fineman JR, Black SM: Increased oxidative stress in lambs with increased pulmonary blood flow and pulmonary hypertension: role of NADPH oxidase and endothelial NO synthase. Am J Physiol Lung Cell Mol Physiol 2006, 290:1069-77.

39. Whiteman M, Armstrong JS, Cheung NS, Siau JL, Rose P, Schantz JT, Jones DP, Halliwell B: Peroxynitrite mediates calcium-dependent mitochondrial dysfunction and cell death via activation of calpains. FASEB J 2004, 18:1395-7.

40. Khan F, Siddiqui AA: Prevalence of anti-3-nitrotyrosine antibodies in the joint synovial fluid of patients with rheumatoid arthritis, osteoarthritis and systemic lupus erythematosus. Clin Chim Acta 2006, 370:100-7.

41. Van der Harst M, Bull S, Brama PA, Barneveld AB, Van Weeren PR, Van de Lest $C$ : Nitrite and nitrotyrosine concentrations in articular cartilage, subchondral bone, and trabecular bone of normal juvenile, normal adult, and osteoarthritic adult equine metacarpophalangeal joints. J Rheumatol 2006, 33:1662-7

42. Nemirovskiy OV, Radabaugh MR, Aggarwal P, Funckes-Shippy CL, Mnich SJ, Meyer DM, Sunyer T, Rodney Mathews W, Misko TP: Plasma 3-nitrotyrosine is a biomarker in animal models of arthritis: Pharmacological dissection of iNOS' role in disease. Nitric Oxide 2009, 20:150-6.

\section{Pre-publication history}

The pre-publication history for this paper can be accessed here: http://www.biomedcentral.com/1471-2474/12/42/prepub

doi:10.1186/1471-2474-12-42

Cite this article as: Cillero-Pastor et al:: Effect of nitric oxide on mitochondrial activity of human synovial cells. BMC Musculoskeletal

Disorders 2011 12:42.

\section{Submit your next manuscript to BioMed Central and take full advantage of:}

- Convenient online submission

- Thorough peer review

- No space constraints or color figure charges

- Immediate publication on acceptance

- Inclusion in PubMed, CAS, Scopus and Google Scholar

- Research which is freely available for redistribution

Submit your manuscript at www.biomedcentral.com/submit
Ciomed Central 